\title{
Culture \& Retail SST: Case of Hypermarkets in Jakarta
}

\author{
B. Balaji, Deblina Saha Vashishta \\ R \& D Centre, Bharathiar University \\ Imperial College of Business Studies, Bangalore, India \\ prof.bbalaji@gmail.com
}

\begin{abstract}
Developing economies like Indonesia are enticing global retailers with an attractive and expanding middle class, and a steadily growing economy. Dynamic changes in retailing across the globe have fostered technological advancements in organised retail. The entire retail experience is now leaning on revolutionary technology. But are all countries world-wide ready to accept this change? The Asian continent is held by strong cultural dimensions like team work, materialistic nature and risk-aversion tendency. Adoption of selfefficacy and acceptance of innovations in technology has a bearing on shopping experiences as compared to dependence on humans. This research paper explores the insights for the same in the Indonesian capital city of Jakarta.
\end{abstract}

\section{Keywords: Cultural, Customer Satisfaction, Retail SST, Technology Revolution}

\section{Introduction}

Countries are increasingly being shaped by citizens' mental stimulus and programming (Hofstede, 1991). A nation's culture in turn depends on a core set of values. Culture varies across countries and close insights into such culture and core values have a huge bearing on survival and growth markets. The diversity of the selfservice technology along with other technological innovations has taken the consumption process to another level altogether. There has been a paradigm shift in retailer's perspective from multichannel business to international expansion. This transformation in the business perspective has been primarily fuelled by increasing options for retailer-consumer interactions. Online purchasing is rising even in developing markets. Growth in e-commerce and mobile commerce is replacing brick and mortar retail in nearly every market. The concept of consumer behaviour is holistic as it is the resultant of culture, values, beliefs and social relationships. Usage of technology or active participation in the technology revolution has also been affected by the cultural factor (Lee et al., 2010) and as a result, SST seems to have negligent success in retail scenario (Dabholkar et al., 2003).

\section{Literature Review}

Consumer Behaviour in relation to Culture and its Dimensions: Collective programming of the mind is what distinguishes different categories or groups of people Hofstede (2001). Culture comprises a set of meaningful symbols, ideas or values that help in communication, interpretation and evaluation by society. The rapid adoption of globalization is assumed to facilitate a borderless world. The reality is otherwise as cultural factors influence many aspects of consumers' buying behaviour. The term "Glocalisation" has come into existence and is definitely reaching vast expanses duly taking care of the local culture (Maheswaran and Sharon, 2000). The consumer is sometimes sceptical about new technology and this is influenced by cultural background. Store loyalty in foreign markets can only be achieved when a positive environment (ambience) is facilitated (Chang and Tu, 2005). Zhang et al. (2008) perused several service-related journals and analysed the issues related to customer service under mixed cultural scenarios. Hofstede (1980) undertook path breaking work on the dimensions of culture and proposed a framework which highlighted collectivism, uncertainty avoidance, femininity, individualism, masculinity, and power of distance

Individualism and uncertainty avoidance play a vital role in consumers' technology adoption (Lim et al., 2004). Individualism is described by a tendency to have concern for oneself and close family with lesser concern for others. People are able to express their opinions and act in a manner oriented to such thoughts. This gives an impetus for people to be open to new concepts and ideas thereby encouraging innovation 
(Erumban and de Jong, 2006). People have their own reasons for pursuing certain actions and tend to be creative at times. Collectivism, in contrast, encompasses strongly bonded groups with high commitment. People in such cultures adhere to the rules and procedures laid down by the group (Erumban and de Jong, 2006). Uncertainty avoidance is not uniform amongst countries. Uncertainty avoidance is dependent on society members' orientation towards the unknown and uninitiated. The level of uncertainty and ambiguity in society has a relation to uncertainty avoidance (Hofstede, 1980). The ability to accept new kinds of products is affected in a negative way by uncertainty avoidance (Yeniyurt and Townsend, 2003).

Self-Service Technology (SST): Only a few studies had taken into account the usage of SST in retail (Weijter et al., 2007). There seems to be negligible focus on the level of consumer satisfaction and its consequence on behavioural intentions of consumers in the future (Chen et al., 2009). Retail SST is characterized by the use of ICT instead of service personnel. Information systems are being continuously updated and adapted to changing needs and e-commerce in retail has also been witnessing a new era. An era where customers themselves are performing the role of service personnel (Meuter et al., 2000). There is a plethora of options under Self-service technologies and they comprise Automated Interactive Voice Response, Automated Bank Teller Machines, and services on the World Wide Web. This phenomenon has gradually become popular in the retail service escape too. Customers can scan the barcode on their purchased items themselves while checkout (exiting the store). This makes checkout clerks redundant (Schliewe and Pezoldt, 2010). The use of such self-help options has not only reduced the manpower requirements but also associated operational costs. SSTs provide advantages in terms of speed, accuracy, and economy.

Indonesia Cultural milieu: Indonesia, being an Asian country, is defined by cultural dimensions which exhibit a low level of masculinity, a practice of collectivism, and the population prefer low to medium levels of avoiding uncertainty. Indonesians exhibit low masculinity when compared with some other Asian country inhabitants. Status and success are more important than materialism in Indonesia. The status held by a person is of paramount importance and the concept is called "gengsi" (outward appearances). "Gengsi" needs to be strongly maintained in order to create an aura of status. There is a strong preference toward separation of two entities: the internal and external. People are expected to practise harmony at the workplace thereby fostering good relationships. People generally desist from transmitting bad or negative news or feedback. The consensus perception of groups would determine if innovations in retail are adopted given the fact that social sensitivity is high and valued.

Hypermarket Scenario: A hypermarket is a big box store which combines the attributes of a supermarket and a department store. It is usually bigger when compared with a supermarket. The typical layout of a hypermarket would be in the range of 1.5 lakh to 3 lakh square feet. Indonesia's organised retail sector has great scope and prospects in the hypermarket sector. There is growing popularity for hypermarkets since they made their entry into the new millennium. Their contribution to the sector has risen to forty percent since the year 2003. The leader in terms of maximum market share is Carrefour. Matahari's outlets numbering 52 and Hero's Giant follow.

\section{Methodology}

The current research was necessitated to analyse the impact of cultural dimensions on SST in hypermarkets of Jakarta. The three main brands of hypermarkets in Jakarta, namely, Carrefour, Lotte Mart and Giant Hero were studied. The research instrument for the survey was adapted from the version propagated by Schliewe and Pezoldt (2010). The instrument was suitably reframed to make it relevant in the context of cultural dimensions proposed by Hofstede's (2001). It is significant to mention here that Hofstede's measurement scale has been validated in numerous studies associated with culture. The measurement scale comprised 4points wherein the lowest agreement level was indicated by 'strong disagreement' while the highest agreement level was indicated by 'strong agreement' with the given statement. The measurement instrument had four constructs, namely, Collectivism, Uncertainty Avoidance, Masculinity, and SST Acceptance. 436 Indonesian consumers were surveyed at Jakarta during. Proportionate Stratified Sampling was employed. The research instrument was found to exhibit high reliability as the Cronbach alpha was 0.816 , greater than the acceptable value of 0.7 (Nunally, 1978). Hypotheses that were formulated were:

$\mathrm{H}_{1}$ : Culture has a significant influence on SST acceptance in hypermarkets. 
$\mathrm{H}_{1 \mathrm{a}}$ : Degree of collectivism has a significant influence on SST acceptance for Indonesian hypermarket consumers.

$\mathrm{H}_{1 \mathrm{~b}}$ : Uncertainty avoidance has a significant influence on SST acceptance for Indonesian hypermarket consumers.

$\mathrm{H}_{1 c}$ : Masculinity has a significant influence on SST acceptance for Indonesian hypermarket consumers.

The content validity of the questionnaire was checked with the help of five experts in the area and through pilot testing of around 50 hypermarket consumers. Required modifications were made to add or delete some statements as per experts' recommendations and advice. Multiple regressions, a statistical technique, were employed to ascertain the significant influence of culture on SST acceptance. Initial and preliminary analysis was done to check on the assumptions required for hierarchical multiple regression. The assumptions are normality, linearity and homoscedasticity. Multicollinearity was ruled out as all the correlations were poor.

\section{Analysis}

The Indonesian sample had the following characteristics: $42 \%$ of the respondents were male while $58 \%$ were female. 53\% used SST for bill payment while 31\% used SST for online shopping. $48 \%$ were working professionals followed by students. 38\% were adults between 21 and 30 years while a similar number were between 31 and 40 years. The results of hierarchical multiple regression analysis using the enter method was used to ascertain the influence of culture dimensions (collectivism, uncertainty avoidance, and masculinity) on SST acceptance are summarised Table 1.

Table 1: Model Summary

\begin{tabular}{|c|c|c|c|c|c|c|c|c|c|}
\hline \multirow[b]{2}{*}{ Model } & \multirow[b]{2}{*}{$\mathbf{R}$} & \multirow[b]{2}{*}{$\begin{array}{l}\text { R } \\
\text { Square }\end{array}$} & \multirow[b]{2}{*}{$\begin{array}{l}\text { Adjusted } \\
\mathbf{R} \\
\text { Square } \\
\end{array}$} & \multirow[b]{2}{*}{$\begin{array}{l}\text { Std. Error } \\
\text { of the } \\
\text { Estimate }\end{array}$} & \multicolumn{5}{|c|}{ Change Statistics } \\
\hline & & & & & $\begin{array}{l}\mathbf{R} \\
\text { Square } \\
\text { Change } \\
\end{array}$ & $\begin{array}{l}\text { F } \\
\text { Change }\end{array}$ & df1 & df2 & $\begin{array}{l}\text { Sig. F } \\
\text { Change }\end{array}$ \\
\hline 1 & $0.532^{\mathrm{a}}$ & 0.269 & 0.262 & 7.15678 & 0.265 & 36.152 & 2 & 289 & 0.000 \\
\hline 2 & $0.621^{\mathrm{b}}$ & 0.368 & 0.362 & 6.68195 & 0.104 & 47.075 & 1 & 288 & 0.000 \\
\hline
\end{tabular}

a. Predictors: (Constant), Collectivism, Uncertainty Avoidance

b. Predictors: (Constant), Collectivism, Uncertainty Avoidance, Masculinity

c. Dependent Variable: SST Acceptance

Model 1 is significant with $\mathrm{F}(2,289)=36.15$; $\mathrm{p}<0.001$ indicating $26.9 \%$ variance in SST acceptance, which is indicated in Table 1. The overall model significance (including all the independent variables) is evident from the ANOVA table (Table 2), with $\mathrm{F}(3,288)=42.63$; $\mathrm{p}<0.001$.

Table 2: ANOVA

\begin{tabular}{llllll}
\hline Model & Sum of Squares & Df & Mean Square & F value & p value \\
\hline $1 \quad$ Regression & 5689.569 & 2 & 1733.26 & 36.152 & $0.000^{\mathrm{a}}$ \\
Residual & 15412.742 & 289 & 48.219 & & \\
Total & 21102.311 & 291 & & & \\
$2 \quad$ Regression & 7354.365 & 3 & 1765.48 & 42.632 & $0.000^{\mathrm{b}}$ \\
Residual & 12756.865 & 288 & 41.754 & & \\
Total & 20111.23 & 291 & & & \\
\hline
\end{tabular}

a. Predictors: (Constant), Collectivism, Uncertainty Avoidance

b. Predictors: (Constant), Collectivism, Uncertainty Avoidance, Masculinity

c. Dependent Variable: SST Acceptance

The hierarchical multiple regressions have been performed in two stages. In the first stage only two predictors were entered (Collectivism and Uncertainty Avoidance) and the model has been found to be 
significant with $\mathrm{F}(2,289)=36.15 ; \mathrm{p}<0.001$ indicating $26.9 \%$ variance in SST acceptance. In the second step, Masculinity was also entered and the whole model is significant at $F(3,288)=42.63$; $p<0.001$, explaining $36.8 \%$ variance in SST acceptance with $\mathrm{R}^{2}$ change $=0.10$. This clearly shown that all the three predictor variables is statistically significant. Hypotheses Testing for Indonesian consumers revealed that all hypotheses were accepted. Collectivism, uncertainty avoidance and masculinity have significant influence on acceptance of SST.

Implications: This research focussed on the impact of culture dimensions on the level of SST acceptance in hypermarkets Future research can be directed on differential parameters, including age groups or generations. It would be beneficial to ascertain whether young consumers (like millennials) would give priority to self-efficacy.

\section{Conclusion}

Indonesians, being highly collectivist with exhibiting low masculinity, are still getting used to the concept of SST. However, there is an emerging trend amongst the younger population who is more receptive to SST acceptance as they are more prone to low uncertainty avoidance.

\section{References}

Chang, C. H. \& Tu, C. Y. (2005). Exploring store image, customer satisfaction and customer loyalty relationship: evidence from Taiwanese hypermarket industry. Journal of American Academy of Business, 7(2), 197-202.

Chen, J. S., Yen, H. J. R., Li, E. Y. \& Ching, R. K. H. (2009). Measuring CRM effectiveness: construct development, validation and application of a process-oriented model. Total Quality Management and Business Excellence, 20(3), 283-299.

Dabholkar, P., Bobbitt, L. \& Lee, E. (2003). Understanding consumer motivation and behaviour related to selfscanning in retailing. International Journal of Service Industry Management, 14(1), 59-95.

Erumban, A. A. \& de Jong, S. B. (2006). Cross-country differences in ICT adoption: a consequence of culture? Journal of World Business, 41(4), 302-314,

Hofstede, G. (1980). Culture's consequences: international differences in work-related values. Beverly Hills: Sage Publications.

Hofstede, G. (1991). Cultures and organizations: software of the mind. London, UK: McGraw-Hill.

Hofstede, G. (2001). Culture's consequences: comparing values, behaviours, institutions, and organizations across nations. Beverly Hills: Sage Publications.

Lee, H., Cho, H., Xu, W. \& Fairhurst, A. (2010). The influence of consumer traits and demographics on intention to use retail self-service checkouts. Marketing Intelligence and Planning, 28(1), 46-58.

Lim, K. H., Leung, K., Sia, C. L. \& Lee, M. K. D. (2004). Is e-commerce boundary-less? Effects of individualismcollectivism and uncertainty avoidance on internet shopping. Journal of International Business Studies, 35(6), 545-559.

Maheswaran, D. \& Sharon, S. (2000). Issues and new directions in cultural psychology. Journal of Consumer Psychology, 9(2), 59-66.

Meuter, M., Ostrom, A., Roundtree, R. \& Bitner, M. (2000). Self-service technologies: understanding customer satisfaction with technology-based service encounters. Journal of Marketing, 64, 50-64.

Nunally, J. C. (1978). Psychometric Theory. New York: McGraw Hill.

Schliewe, J. \& Pezoldt, K. (2010). A cross-cultural comparison of factors influencing self-scan checkout use. Journal of Business \& Economics Research, 8(10), 39-47.

Weijters, B., Devarajan, R., Falk, T. \& Schillewaert, N. (2007). Determinants and outcomes of customers' use of self-service technology in a retail setting. Journal of Service Research, 10(1), 3-21.

Yeniyurt, S. \& Townsend, J. D. (2003). Does culture explain acceptance of new products in a country? An empirical investigation. International Marketing Review, 20(4), 377-396.

Zhang, J., Beatty, S. E. \& Walsh, G. (2008). Review and future directions of cross-cultural consumer service research. Journal of Business Research, 61, 211-224. 